\title{
PENGARUH ELECTRONIC WORD OF MOUTH (E-WOM) DAN DAYA TARIK TERHADAP KEPUTUSAN BERKUNJUNG WISATAWAN DI PINUS PENGGER KABUPATEN BANTUL
}

\author{
Yuliyani \\ Akademi Pariwisata STIPARY, Yogyakarta, email: yulia.stipary@gmail.com
}

Suharto

Akademi Pariwisata STIPARY, Yogyakarta, Indonesia, email: hartamas1970@gmail.com

\begin{abstract}
ABSTRAK
Histori Artikel

Submitted:

10 Desember 2020

Reviewed:

28 Desember 2020

Accepted:

8 Januari 2021

Published:

15 Mei 2021

Penelitian ini bertujuan untuk mengetahui pengaruh electronic word of mouth, dan daya tarik terhadap keputusan berkunjung wisatawan di Pinus Pengger. Populasi dalam penelitian ini adalah para wisatawan obyek wisata Pinus Pengger yang mempunyai Instagram. Sampel yang diambil sebanyak 100 responden. Pengambilan sampel menggunakan teknik accidental sampling. Teknik pengumpulan data dengan kuesioner. Analisis data menggunakan teknik analisis regresi berganda. Hasil penelitian ini menunjukkan bahwa secara bersama-sama electronic word of mouth, dan daya tarik berpengaruh terhadap keputusan berkunjung wisatawan di Pinus Pengger. Secara parsial electronic word of mouth berpengaruh terhadap keputusan berkunjung wisatawan, sedangkan daya tarik tidak berpengaruh keputusan berkunjung wisatawan.
\end{abstract}

Kata kunci : electronic word of mouth, daya tarik, keputusan berkunjung.

\section{THE INFLUENCE OF ELECTRONIC WORD OF MOUTH, AND ATTRACTION TOWARDS TOURIST DECISIONS TO VISIT PINUS PENGGER BANTUL ABSTRACT}

This research attempts to learn the influence of electronic word of mouth and location towards tourist decisions to visit at the Pinus Pengger. The population in this research is the tourists who visited Pinus Pengger. The sample taken was 100 respondents. The method for the sampling is accidental sampling. Data collection technique was questionnaire. The analysis of data used multiple regression analysis techniques. The results of this study indicate that together, electronic word of mouth, and attractiveness affect the decision to visit tourists in Pinus Pengger. Partially, electronic word of mouth affects the decision to visit tourists, while attractiveness does not affect the decision to visit tourists.

Keywords: electronic word of mouth, attraction, tourist decision.

\section{PENDAHULUAN}

Indonesia merupakan negara kepulauan yang tersebar dari Sabang sampai Merauke. Setiap provinsi atau daerah di Indonesia memiliki keanekaragaman sumber daya alam, budaya, sejarah untuk dikembangkan menjadi pariwisata unggulan di masing-masing provinsi tersebut. Dengan adanya kunjungan wisatawan ke masing-masing provinsi tersebut, akan berpengaruh terhadap meningkatnya Pendapatan Asli Daerah (PAD) dan devisa bagi Negara. Pariwisata merupakan komoditas yang dibutuhkan oleh setiap individu, karena berwisata bisa menghilangkan kejenuhan, mengetahui peninggalan sejarah dan budaya, bisa 
berbelanja dan bisnis, (Austriana, 2005).

Yogyakarta merupakan salah satu provinsi yang selalu berusaha mendatangkan dan meningkatkan jumlah kunjungan wisatawan domestik maupun mancanegara setiap tahunnya (Statistik Kepariwisataan Dinpar Yogyakarta, 2019).

Tidak mengherankan apabila kunjungan wisatawan dari tiap tahunnya selalu meningkat, hal tersebut dikarenakan Yogyakarta memiliki banyak destinasi wisata yag telah dikenal secara luas oleh wisatawan domestik maupun mancanegara. Destinasi wisata tersebut berupa destinasi wisata alam, wisata buatan, wisata sejarah, wisata budaya, wisata religi, wisata kuliner dan wisata lainnya untuk menarik minat wisatawan. Ada banyak destinasi wisata di Yogyakarta yang telah dikenal baik wisatawan domestik ataupun wisatawan mancanegara diantaranya: Malioboro, Kawasan Tugu Yogyakarta, Keraton Yogyakarta, Candi Prambanan, dan Pantai Parangtritis.

Meskpiun telah banyak memiliki destinasi wisata unggulan, Yogyakarta tidak pernah berhenti untuk menghadirkan suasana baru bagi setiap wisatawan yang berkunjung ke Yogyakarta. Hal tersebut dilakukan agar wisatawan tidak merasa bosan ketika berkunjung di Yogyakarta. Pada saat ini bermunculan destinasi wisata baru di Yogyakarta. Destinasi wisata baru tersebut tersebar di semua kabupaten yang berada di wilayah Yogyakarta. Pada tahun 2018, menurut buku statistik Statistik Kepariwisataan Dinas Pariwisata Yogyakarta tahun 2018 di Yogyakarta terdapat 185 destinasi wisata, sedangkan pada tahun 2019 menurut Statistik Kepariwisataan Dinas Pariwisata Yogyakarta tahun 2019 di Yogyakarta terdapat 215 destinasi wisata, yang meliputi destinasi wisata alam, buatan, budaya, dan desa/ kampung wisata. Dari data tersebut dapat diartikan bahwa pada kurun waktu satu tahun, terdapat penambahan sebanyak 30 destinasi wisata baru di Yogyakarta. Salah satu kabupaten yang berusaha menghadirkan destinasi wisata baru adalah kabupaten Bantul.
Kabupaten Bantul merupakan salah satu kabupaten di Yogyakarta yang memiliki beragam destinasi wisata dari mulai wisata alam, budaya, sejarah, kuliner, taman taman hiburan, sentra industri kerajinan dan lain sebagainya. Menurut buku Statistik Kepariwisataan Dinas Pariwisata Yogyakarta tahun 2019 di kabupaten Bantul sendiri terdapat 48 destinasi wisata.

Destinasi wisata tersebut tersebar di hampir semua kecamatan yang berada di wilayah Bantul. Masing - masing kecamatan di Bantul berusaha memanfaatkan sumber daya alam yang dimilikinya untuk dijadikan destinasi wisata sebagai cara menarik wisatawan untuk berkunjung. Dengan keanekaragaman destinasi wisata yang dimilikinya, diharapkan Kabupaten Bantul dapat secara optimal mendukung tercapainya target kunjungan wisatawan ke Yogyakarta. Salah satu kecamatan di Bantul yang saat ini menjadi incaran bagi wisatawan adalah kecamatan Dlingo.

Salah satu destinasi wisata di Kecamatan Dlingo adalah Pinus Pengger. Pinus Pengger terletak di Desa Gunung Cilik, Desa Muntuk, Kecamatan Dlingo, Kabupaten Bantul, Yogyakarta. Pinus Pengger semakin dikenal luas dikarenakan para wisatawan mendapatkan informasi dari mulut ke mulut atau melalui media jejaring sosial salah satunya adalah Instagram. Setiap tahunnya jumlah pengunjung ke Pinus Pengger semakin bertambah (Arsip Pengelola Pinus Pengger, 2019).

Adapun akun instagram yang dimiliki oleh Pinus Pengger yaitu@pinuspengger. Dapat dilihat dari akun tersebut bahwa per tanggal 30 Juli 2020 sudah memiliki 7.505 pengikut dan 440 postingan. Sehingga dengan kepemilikan akun instagram Pinus Pengger, menjadikan keberadaan destinasi wisata ini menyebar dengan sangat cepat melalui media jejaring sosial tersebut. Hal tersebut dikarenakan kegemaran para wisatawan saat ini untuk mengupload photo ataupun video ke akun Instagram mereka ketika mengunjungi destinasi wisata tidak terkecuali Pinus Pengger. 
Menurut Weiss (2012), keberadaan suatu informasi wisata yang dipublikasikan melalui media sosial baik berupa teks dan gambar dapat mempengaruhi pola pikir dan sudut pandang pengunjung pentingnya mendukung konservasi lingkungan. Sedangkan menurut Kiralova (2014), penggunaan media sosial sebagai salah satu strategi komunikasi juga mempengaruhi perilaku pengunjung dalam menarik minat mereka terhadap daerah tujuan wisata.

Selain itu, menurut Zarrella (2010), mengemukakan bahwa Media sosial adalah perkembangan mutakhir dari teknologiteknologi web baru berbasis internet yang memudahkan semua orang untuk berkomunikasi, berpartisipasi, saling berbagi, dan membentuk suatu jaringan online, sehingga dapat menyebarluaskan konten mereka sendiri. Media sosial yang bisa disebut juga jejaring sosial adalah suatu layanan berbasis web yang memungkinkan setiap individu untuk membangun hubungan sosial melalui dunia maya seperti membangun profil tentang dirinya sendiri, menunjukkan koneksi seseorang dan memperlihatkan hubungan apa saja yang ada antara satu pemilik dengan pemilik akun lainnya dalam sistem yang disediakan, dimana masing-masing jejaring sosial memiliki ciri khas dan sistem yang berbedabeda (Boyd dan Ellison:2007).

Fenomena para wisatawan yang sering mengunggah photo atau video melalui instagram tentang destinasi wisata dapat menjadi salah satu media promosi. Menurut Mitchell (2017), dengan angka pengguna Instagram yang sangat tinggi, banyak para pelaku bisnis yang memanfaatkan hal ini yaitu dengan mempromosikan produk mereka melalui sosial media Instagram. Hal tersebut dikarenakan proses Visualisasi dalam sosial media mampu menimbulkan sebuah persepsi bagi pengguna yang melihatnya dan akan menimbulkan sebuah citra baik dan buruk bergantung pada karakteristik gambar yang diterima (Kertamukti, 2015).

Selain itu, Informasi yang ditulis oleh wisatawan yang pernah berkunjung akan memberikan nilai tambah cukup besar bagi users lain yang merupakan calon wisatawan potensial. Hal ini dapat mempercepat berkembangnya electronic word of mouth dan akhirnya akan mempengaruhi keputusan berkunjung wisatawan. (Ali Hasan, 2015).

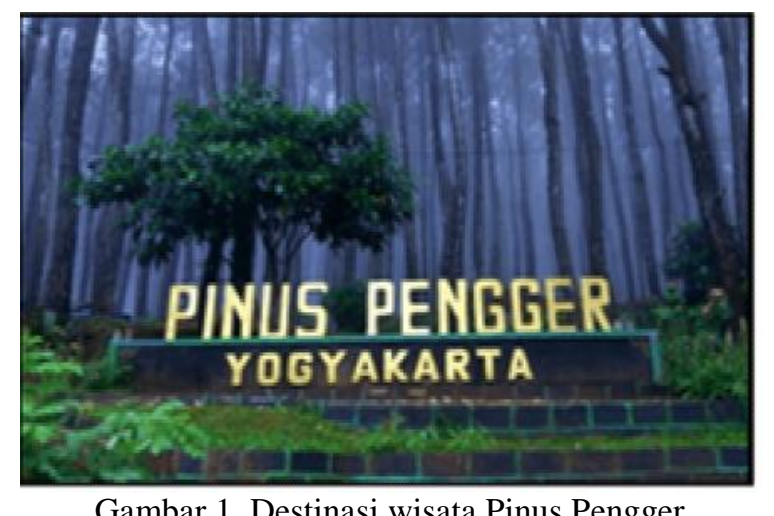

Gambar 1. Destinasi wisata Pinus Pengger Sumber: Dokumen Pribadi

Sehingga dari unggahan photo atau video di akun Instagram para wisatawan ketika berkunjung ke Pinus Pengger, maka akan menimbulkan rasa ketertarikan dan penasaran bagi wisatawan yang belum pernah mengunjungi Pinus Pengger. Wisatawan yang belum pernah mengunjungi Pinus Pengger akan menuliskan pesan di kolom komentar atau memberikan tanda Like/ suka di akun Instagram pada Photo atau Video yang menampilkan tentang Pinus Pengger.

Komentar atau tanda Like/Suka yang ditinggalkan dan komentar dituliskan pada kolom Instagram menunjukkan bahwa komunikasi word of mouth tidak hanya dilakukan secara langsung tetapi juga bisa melalui media elektronik yang sering disebut Electronic Word of Mouth (E-WoM). Menurut Illah (2019), dalam media sosial Instagram, comment positif atau negatif dari pengguna yang telah melakukan perjalanan wisata ke sebuah destinasi, akan mempengaruhi keputusan mereka yang belum pernah melakukan perjalanan wisata untuk berkunjung. Hennig - Thurau et al. (dalam Puspa Ratnaningrum et al. 2016:3), mengemukakan bahwa electronic word of mouth adalah pernyataan positif ataupun negatif yang dilakukan oleh pelanggan potensial ataupun mantan pelanggan tentang 
produk atau perusahaan, yang ditujukan untuk banyak orang atau lembaga via internet. Dari sinilah kekuatan electronic word of mouth (E-WoM) dapat mempengaruhi terhadap minat dan keputusan berkunjung wisatawan.

Dari uraian latar belakang tersebut diatas, maka peneliti merasa tertarik untuk melakukan penelitian mengenai sejauh mana pengaruh electronic word of mouth (E-WoM) dan daya tarik, mempengaruhi keputusan wisatawan berkunjung di Pinus Pengger.

Adapun tujuan dari penelitian ini adalah untuk: Mengetahui electronic word of mouth (E-WoM) dan daya tarik secara parsial berpengaruh terhadap keputusan berkunjung wisatawan di destinasi wisata Pinus Pengger dan Mengetahui electronic word of mouth (E-WoM) dan daya tarik secara bersamasama berpengaruh terhadap keputusan berkunjung wisatawan di Obyek wisata Pinus Pengger.

\section{LITERATUR REVIEW}

\section{Electronic Word Of Mouth (E-Wom)}

Sekarang ini, internet telah mengubah gaya hidup masyarakat dengan banyak cara. Internet memberikan kemudahan bagi penggunanya terlebih pada informasi yang sangat mudah diakses. Bahkan sekarang ini pemasaran produk barang atau jasa banyak dilakukan melalui internet. Pengelola destinasi wisata sekarang ini semakin kreatif dalam memasarkan produk. Dengan adanya internet terciptalah sebuah paradigma baru dalam komunikasi Word of Mouth dan inilah awal kemunculan dari istilah electronic Word of Mouth.

Secara umum Word of Mouth adalah oral person-to-person communication atau komunikasi lisan antara individu ke individu lainnya atau antara pengirim dan penerima pesan dimana didalamnya memiliki unsur produk, jasa ataupun brand. Kotler \& Keller (2012) mengemukakan bahwa, word of mouth communication atau komunikasi dari mulut ke mulut merupakan proses komunikasi yang berupa pemberian rekomendasi baik secara individu maupun kelompok terhadap suatu produk atau jasa yang bertujuan untuk memberikan informasi secara personal.

Menurut henning-thurau, et, al. (2004), dalam ismagilova, dkk. (2017) electronic word of mouth is any positive of negative statement made by potential, actual, or former customers about a product or company which is made available to multitude of the people and institutes via the internet. Setiap wisatawan yang sudah pernah mengetahui keberadaan destinasi wisata melalui media sosial memiliki kecenderungan untuk memberikan komentar atau ulasan pada destinasi wisata tersebut. Menurut Charo et.al., (2015) bahwa bentuk pertukaran informasi dan pengetahuan secara online pada media sosial dikenal sebagai Electronic Word of Mouth (E-WOM). Selain itu, menurut Jalilvand dan Samiei (2012), penggunaan internet dan jejaring sosial yang meningkat juga merupakan hal yang penting dimana saat ini Word of Mouth tidak hanya dilakukan perorangan namun bisa dalam bentuk apa saja termasuk internet yang disebut dengan Electronic Word of Mouth (eWOM).

Rekomendasi dari orang lain memiliki pengaruh yang besar dalam keputusan untuk mengunjungi suatu destinasi wisata. Apalagi, bila rekomendasi tersebut berasal dari orang yang dikenal. Menurut Cheung dan Lee (2012) ada beberapa keunggulan Electronic Word of Mouth yang lebih berpengaruh dari pada tradisional word of mouth, yaitu: (1) Electronic word of mouth lebih modern yaitu penggunaan informasi melalui teknologi; (2) Electronic word of mouth lebih mudah diakses daripada traditional WOM. Sebagian besar informasi berbasis teks di internet yang dapat diarsipkan yang kemudian hari dapat diakses kembali; (4) Sifat dari Electronic word of mouth dimana tidak dapat melakukan penilaian kredibilitas dari pengirim dan pesannya. Seseorang hanya dapat menilai kredibilitas komunikator melalui sistem reputasi online, jadi pesan 
dalam sebuah electronic word of mouth akan menjadi sangat penting sebagai referensi dalam memudahkan konsumen untuk melakukan keputusan pembelian. HennigThurau et.al., (2004) merefleksikan electronic word of mouth melalui delapan dimensi sebagai berikut: (1) Platform (2) Assistance, (3) Concern for Other, (4) Economic, (5) Helping Expressing Positive Emotions, (6) Venting Negative Feelings, (7) Social Benefits, (8) Advice Seeking.

Kekuatan konten dan komentar yang terjadi di dalam sosial media mendorong banyak pengelola destinasi wisata yang memanfaatkan sebagai alat komunikasi dan pemasaran mereka. Melalui sosial media pengelola destinasi wisata dapat mempromosikan daya tarik ditempat tersebut dan membentuk komunitas atau group online untuk wisatawan yang menyukai destinasi wisata tertentu. Adanya komunitas atau group online tersebut akan memungkinkan terjadinya suatu interaksi sosial secara elektronik yang akan mendorong terjadinya electronic word of mouth. Banyak pengelola destinasi wisata menyadari kekuatan dari electronic word of mouth di sosial media. Jaringan sosial dalam bentuk komunitas online dapat menjadi sumber daya penting bagi keberlangsungan suatu destinasi wisata, tidak terkecuali destinasi wisata Pinus Pengger. Adapun akun isntagram yang dimiliki adalah@pinuspengger.

\section{Daya Tarik}

Berdasarkan Undang-Undang Republik Indonesia No. 10 tahun 2009 tentang Kepariwisataan, daya tarik wisata dijelaskan sebagai segala sesuatu yang memiliki keunikan, kemudahan, dan nilai yang berupa keanekaragaman kekayaan alam, budaya, dan hasil buatan manusia yang menjadi sasaran atau kunjungan wisatawan dan disebutkan bahwa daya tarik wisata adalah suatu yang menjadi sasaran wisata terdiri atas : Daya tarik wisata ciptaan Tuhan Yang Maha Esa yang berwujud keadaan alam, flora dan fauna; Daya tarik wisata hasil karya manusia yang berwujud museum, peninggalan sejarah, seni dan budaya, wisata agro, wisata buru, wisata petualangan alam, taman rekreasi dan komplek hiburan; Daya tarik wisata minat khusus, seperti : berburu, mendaki gunung, gua, industri dan kerajinan, tempat perbelanjaan, sungai air deras, tempat-tempat ibadah, tempat ziarah dan lain-lain.

Sedangkan menurut Maryani (2012) suatu daya Tarik wisata dapat menarik untuk dikunjungi oleh wisatawan harus memenuhi syarat-syarat untuk pengembangan daerahnya, syarat - syarat tersebut adalah: (1) What to see: Di tempat tersebut harus ada objek dan atraksi wisata yang berbeda dengan yang dimiliki daerah lain. Dengan kata lain daerah tersebut harus memiliki daya tarik khusus dan atraksi budaya yang dapat dijadikan "entertainment" bagi wisatawan. What to see meliputi pemandangan alam, kegiatan, kesenian dan atraksi wisata (2) What to do: Di tempat tersebut selain banyak yang dapat dilihat dan disaksikan, harus disediakan fasilitas rekreasi yang dapat membuat wisatawan betah tinggal lama ditempat itu. (3) What to buy: Tempat tujuan wisata harus tersedia fasilitas untuk berbelanja terutama barang souvenir dan kerajinan rakyat sebagai oleh-oleh untuk di bawa pulang ke tempat asal.

Suwena dan Widyatmaja dalam Junaida (2019) menyatakan wisatawan dalam melakukan aktivitas perjalanannya itu dirangsang atau ditimbulkan oleh adanya "sesuatu yang menarik", yang lazim disebut daya tarik wisata (tourism attraction, tourist attraction), yang dimiliki tempat kunjungan tersebut, baik untuk kepentingan bisnisnya maupun sebagai tempat pesiar, misalnya iklim tropis yang hangat, iklim ekonomi yang kondusif buat investasi, maupun kegiatan lainnya. Sedangkan Danang (2014) menyatakan bahwa informasi dari mulut ke mulut (word of mouth) ialah pelanggan akan berbicara kepada pelanggan lain atau masyarakat lainnya tentang pengalamannya menggunakan produk yang dibelinya.

Zaenuri (2012) menyatakan bahwa di dalam sistem kepariwisataan terdapat empat indikator tujuan wisata yang saling 
mendukung yaitu: (1) Attractions atau Daya Tarik Wisata. Secara umum dapat dipilah dalam daya tarik alam, daya tarik budaya, dan daya tarik buatan, (2) Amenities atau fasilitas (layanan pendukung wisata). Hal ini meliputi akomodasi dan jasa boga, serta aneka jasa lain, termasuk retail dan jasa rekreasi lainnya, (3) Access atau pencapaian, baik menuju ke maupun di dalam daerah tujuan, (4) Ancillary Services, yang meliputi kegiatan pemasaran, pengembangan, serta koordinasi.

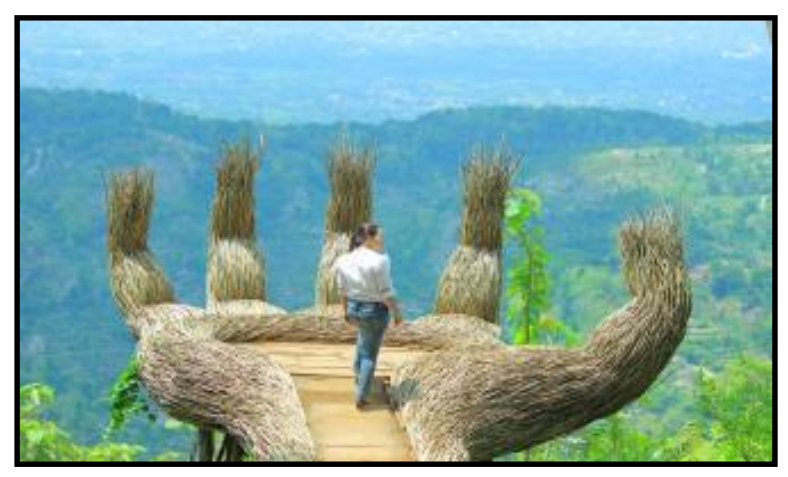

Gambar 2. Spot Photo Tangan Pancawara Pinus Pengger

Sumber: Dokumen Pribadi

Daya tarik yang dimiliki oleh destinasi wisata Pinus Pengger antara lain: (1) Keberadaan pohon pinus yang akan memberikan kesejukan selama berwisata di Pinus Pengger. (2) Wisatawan dapat melakukan kegiatan camping atau berkemah di kawasan destinasi wisata Pinus Pengger. Untuk dapat melakukan camping ditempat ini, wisatawan akan dikenakan tarif sebesar Rp. 15.000,- (3) Adanya berbagai spot photo yang dapat dipilih oleh wisatawan. Ada 9 (sembilan) spot photo yang dapat dipilih yaitu: Tangan Pancawara, Antar Gatha, Cetta Abipraya, Jembatan Baswara, Askamaya Saskara, Jembatan Pohon Pinus Pengger, Hammock Area, Assuma Paduraksa, Sabrang Aninda (4) Wisata tour dengan menggunakan mobi Jeep.

\section{Instagram}

Berkembangnya media sosial saat ini tentunya berbanding lurus dengan berkembangnya teknologi komunikasi. Era smartphone menjadi tonggak majunya media sosial. Hal ini dikarenakan semenjak kemunculannya, mulai banyak media sosial yang bermunculan sehingga mempermudah proses komunikasi. Instagram merupakan salah satu bentuk hasil dari kemajuan internet dan tergolong salah satu media sosial yang cukup digandrungi oleh khalayak masa kini khususnya anak muda. Pengguna Instagram didominasi anak muda usia 18 tahun sampai 24 tahun.

Hal ini dapat dibuktikan dengan meningkatnya pengguna instagram pada setiap tahunnya. Terhitung pada April 2017 lalu, Instagram mengumumkan bahwa pengguna aktif bulanannya telah mencapai kisaran 800 juta akun dan angka tersebut lebih banyak dibandingkan tahun sebelumnya (Yusuf, 2017). Instagram berasal dari kata "instan" atau "insta", seperti kamera polaroid yang dulu lebih dikenal dengan "foto instan" (Pengertian instagram, dalam http://.id.wikipedia.org./wiki/instagram, diakses pada tanggal 26 Juli 2020).

Sedangkan menurut Putri mengemukakan bahwa Instagram berasal dari kata "instan-telegram", karena Instagram juga dapat menampilkan foto-foto secara instan dalam tampilannya. Sedangkan untuk kata "gram" berasal dari kata "telegram", dimana cara kerja telegram adalah untuk mengirimkan informasi kepada orang lain dengan cepat. Begitu pula dengan Instagram yang dapat mengunggah foto dengan menggunakan jaringan internet, sehingga informasi yang disampaikan dapat diterima dengan cepat.

Berbeda dengan media sosial lainnya, instagram menitik beratkan kepada postingan foto dan video dari para penggunanya. Keunikan yang membuat instagram satu ini berbeda dengan media sosial pada umumnya. Apalagi, instagram seringkali memperbaharui sistemnya. Sejak kemunculannya pada tahun 2010 silam, instagram sering memperbarui fitur yang ada sehingga fiturnya lebih lengkap dan lebih menarik. Berikut adalah fitur-fitur yang ada di instagram pada saat ini: (a) Pengikut (Follower) dan Mengikuti (Following); (b) Mengunggah Foto/Video dengan Caption (Posting). Kegunaan utama dari Instagram 
adalah sebagai tempat untuk mengunggah dan berbagi foto atau video kepada pengguna lainnya; (c) Kamera Foto yang telah diambil melalui aplikasi Instagram dapat disimpan; (d) Efek (Filter) Pada versi awalnya, Instagram memiliki efek-efek yang dapat digunakan oleh para pengguna pada saat mereka hendak menyunting sebuah foto; (e) Arroba Seperti Twitter dan juga Facebook, Instagram juga memiliki fitur yang dimana para penggunanya dapat menyinggung pengguna yang lainnya., dengan menambahkan arroba (@) dan memasukkan nama akun Instagram dari pengguna lainnya tersebut. (f) Label foto (Hashtag) Sebuah label di dalam Instagram adalah sebuah kode yang memudahkan para pengguna untuk mencari foto tersebut dengan menggunakan kata kunci. (g) Geotagging Setelah memasukkan judul foto tersebut, bagian selanjutnya adalah bagian Geotag. Dengan geotagging para pengguna dapat terdeteksi dimana mereka telah mengambil foto tersebut atau dimana foto tersebut telah diunggah. (h) Jejaringan sosial

Dalam membagi foto tersebut, para pengguna juga tidak hanya dapat membaginya di dalam Instagram saja, melainkan foto tersebut dapat dibagi juga melalui jejaring sosial lainnya seperti Facebook dan Twitter dengan cara menghubungkan link akun Instagram dengan akun media sosial lainnya. (i) Tanda suka Instagram juga memiliki sebuah fitur tanda suka yang dimana fungsinya sama seperti apa yang ada di Facebook, yaitu sebagai penanda bahwa pengguna yang lain menyukai foto yang telah diunggah oleh pengguna lain. (j) Instastory merupakan singkatan dari Instagram stories. Instastory ini adalah salah satu fitur instagram yang memungkinkan para penggunanya untuk membagikan foto atau video yang akan terhapus secara otomatis dalam waktu 24 jam setelahnya. (k) Arsip Foto Fitur ini berfungsi sebagai media pribadi atau seperti album pribadi. (1) Closefriend Pada fitur ini, pengguna dapat membagikan foto atau video yang hanya bisa diakses oleh pennguna lain yang telah dipilih sebagai "CloseFriend". (m) Siaran langsung Fitur ini memungkinkan pengguna dalam sebuah akun untuk melakukan siaran video secara langsung tanpa berbatas waktu yang akan dinikmati oleh pengikutnya. (n) IG TV Fitur ini memungkinkan pengguna untuk mengunggah video lebih dari 1 menit, namun tidak tersimpan dalam Feed profil unggahan.

Sedangkan menu utama pada aplikasi instagram hanya ada 5 (Lima) yang terletak pada dibagian bawah, yaitu: (1) home page, (2) popular, (3) take photo, (4) new feed, dan (5) profile. Penggunaan aplikasi instagram terbilang sangat mudah. Setelah pengguna akun instagram login pada aplikasi tersebut, maka pengguna dapat menjalankan aplikasi tersebut dan digunakan untuk mengupload photo, video, teks, siaran langsung dan unggahan tersebut akan muncul ke sesama pengguna instagram. Setiap foto yang ada di Instagram dapat dikomentari sehingga pengguna instagram lain dapat menulis kesan-kesan mengenai foto. Sesama pengguna Instagram dapat saling memberikan like dan komentar untuk foto yang diunggah di akunnya. Akun alamat instagram yang dimiliki oleh destinasi wisata Pinus Pengger adalah @Pinus Pengger. Jumlah pengikut (follower) saat ini adalah 7.334, sedangkan jumlah postingan sampai saat ini berjumlah 440 berupa photo dan video.

Menurut Schiffman dan Kanuk (dalam Sumarwan, 2011), keputusan merupakan suatu tindakan dari dua atau lebih pilihan alternatif. Semua aspek dari afeksi dan kognisi terlibat dalam pembuatan keputusan. Proses kunci didalam pembuatan keputusan konsumen ialah proses integrasi yang mana pengetahuan dikombinasikan untuk mengevaluasi dua atau lebih alternatif perilaku kemudian memilih satu. Schiffman dan Kanuk (dalam Sumarwan, 2011) mengemukakan empat macam perspektif dari model manusia (model of man). Menurut Sumarwan (2011), proses keputusan konsumen dibagi menjadi enam proses, yaitu: (a) Pengenalan kebutuhan (b) Pemilikan produk (c) Konsumsi produk (d) Perbedaan individu (e) Pengaruh pemasaran (f) Pencarian informasi (g) Pencarian 
informasi (h) Pembelian (i) Kepuasan.

Berdasarkan teori dan kerangka berpikir yang sudah diuraikan sebelumnya, maka hipotesis yang dibangun pada penelitian ini adalah:

H1 : Electronic word of mouth, dan daya tarik secara parsial berpengaruh terhadap keputusan berkunjung wisatawan di obyek wisata Pinus Pengger.

H2 : Electronic word of mouth, dan daya tarik secara bersama-sama berpengaruh terhadap keputusan berkunjung wisatawan di obyek wisata Pinus Pengger.

\section{METODE}

Jenis penelitian yang dilakukan adalah studi kasus. Studi kasus pada dasarnya mempelajari secara intensif seseorang individu atau kelompok yang dipandang mengalami kasus tertentu. Penelitian studi kasus bertujuan secara khusus menjelaskan dan memahami obyek yang diteliti sebagai kasus. Metode pengumpulan data pada penelitian ini menggunakan Kuesioner. Kuesioner adalah metode pengumpulan data yang dilakukan dengan cara memberikan pertanyaan-pertanyaan kepada responden dengan panduan kuesioner. Penyebaran kuesioner dilakukan dengan cara mendatangi pengunjung yang sedang berwisata di obyek wisata Pinus Pengger yang memiliki akun isntagram. Adapun Waktu penelitian adalah pada bulan Juli 2020 .

Sumber data primer yang digunakan pada penelitian ini adalah pengunjung yang berkunjung ke destinasi wisata Pinus Pengger. Sedangkan yang dimksud data sekunder diperoleh dari majalah, surat kabar, buku-buku panduan dan lainnya. Teknik pengambilan sampel yang digunakan pada penelitian ini adalah Pengambilan sampel dalam penelitian ini dilakukan menggunakan non- probabilitas dengan metode Accidental Sampling. Accidental Sampling yaitu pengambilan sampel didasarkan pada kenyataan bahwa mereka kebetulan muncul.
Responden untuk pengambilan sampel adalah bagian dari populasi penelitian yang ditemui di obyek wisata Pinus Pengger.

Adapun teknik pengujian pada penelitian ini antara lain akan menggunakan: (1) Uji validitas digunakan untuk mengukur sah atau valid tidaknya suatu kuesioner. Uji validitas yaitu suatu ukuran yang menunjukkan sejauh mana alat ukur yang digunakan mengukur variabel yang akan diukur (Martono, 2014) (2) Uji reliabilitas merupakan alat untuk mengukur kehandalan, ketetapan atau konsistensi suatu kuesioner. Reliabilitas yaitu ketetapan hasil penelitian apabila hasil penelitian diulang dua kali atau lebih (Martono, 2014). Untuk itu peneliti menggunakan alat bantu program SPSS for windows. SPSS memberikan fasilitas untuk mengukur reliabilitas dengan uji statistik Cronbach Alpha. Suatu variabel dikatakan reliabel jika memberikan nilai $\alpha>0,60$. Sedangkan teknik analisa data pada penelitian ini adalah: (1) Analisa Regresi; Linier Berganda; (2) Uji Asumsi Klasik; (3) Uji Hipotesis.

Adapun kerangka penelitian pada penelitian ini adalah digambarkan sebagai berikut:

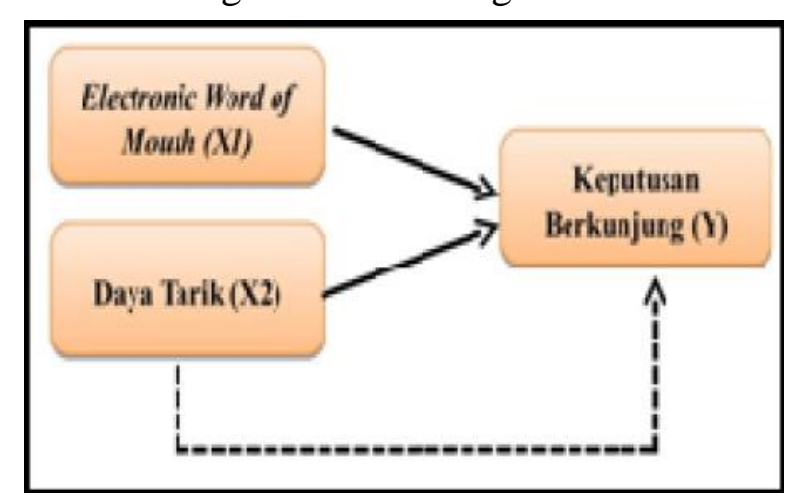

\section{HASIL DAN PEMBAHASAN}

\section{Pinus Pengger}

Kecamatan Dlingo terletak di sisi timur ibukota Kabupaten Bantul dan berbatasan langsung dengan Kabupaten Gunungkidul. Kecamatan Dlingo memanfaatkan kawasan hutan pinus sebagai daya tarik pengunjung. Salah kawasan hutan pinus yang dimanfaatkan sebagai destinasi wisata adalah 
Pinus Pengger. Pinus Pengger terletak di Desa Gunung Cilik, Desa Muntuk, Kecamatan Dlingo, Kabupaten Bantul, Yogyakarta. Pinus Pengger memiliki luas 97,2 hektar namun yang dikelola oleh masyarakat hanya 4,4 hektar.

Sebelum menjadi obyek wisata, pohon pinus yang terdapat di Pinus Pengger disadap getahnya oleh Kelompok Tani Hutan yang kemudian setelah menyadari bahwa kegiatan tersebut dapat merusak hutan dan menyadari bahwa ada potensi wisata, sekelompok pemuda asal Desa Terong mengajak Kelompok Tani Hutan untuk bersama-sama mengelola Hutan Pinus tersebut menjadi sebuah tempat yang dapat dikunjungi oleh wisatawan. Objek wisata Pinus Pengger resmi dibuka untuk wisatawan tepatya pada tanggal 10 April 2017. Agar operasional di objek wisata Pinus Pengger dapat berjalan lancar setiap harinya, maka dibentuklah pengurus atau pengelola. Adapun jumlah keseluruhan pengelola objek wisata adalah 41 (empat puluh satu) orang. Pengelola tersebut berasal dari warga Sendangsari yang memiliki tugas dan tanggung jawab masingmasing. Jumlah Rata - rata pengelola yang berjaga pada siang hari berjumlah $10-12$ orang, sedangkan pada malam hari berjumlah $7-8$ orang.

Agar para wisatawan dapat menikmati indahnya panorama yang ditawarkan di objek wisata Pinus Pengger, wisatawan haya dikenakan tiket masuk sebesar Rp. 3.000,per orang, sedangkan untuk tarif parkir mobil dikenakan tarif Rp. 5.000,- dan untuk sepeda motor sebesar Rp. 3.000,-. Berikut merupakan tiket masuk, tiker parkir mobil di objek wisata Pinus Pengger: Objek wisata Pinus Pengger setiap harinya beroperasional dari pagi hingga malam. Adapun jam buka objek wisata Pinus Pengger mulai dari jam 07.00 sampai dengan jam 23.00 setiap harinya.

Daya tarik yang ditawarkan kepada pengunjung di destinasi wisata Pinus Pengger adalah keberadaan pohon pinus dan pemandangan alamnya. Sedangkan kegiatan yang dapat dilakukan oleh para wisatawan di destinasi wisata ini antara lain: camping, panorama dan swaphoto dan menggunakan jasa mobil Jeep untuk menyusuri destinasi wisata di kawasan Dlingo. Sedangkan fasilitas yang ada di destinasi wisata Pinus Pengger antara lain: tempat cuci tangan, toilet (kamar mandi), Aula, Mushola, Warung Makan, Papan Petunjuk, Tempat Sampah, Kantor Sekretariat, dan Tempat parkir.

\section{Karakteristik Responden Berdarsarkan Usia}

Tabel 1. Tabel Karakteristik Responden Berdarsarkan Usia

\begin{tabular}{ccc}
\hline Usia & Frekuensi & Prosentase \% \\
\hline$\leq 15$ tahun & 25 & 25 \\
$16-25$ tahun & 40 & 40 \\
$26-35$ tahun & 23 & 23 \\
$36-45$ tahun & 10 & 10 \\
$\geq 46$ tahun & 2 & 2 \\
Total & 100 & 100 \\
\hline
\end{tabular}

Sumber: Data Primer

Berdasarkan tabel tersebut diatas dapat dianalisa bahwa sebagian besar responden berusia 16 - 25 tahun dengan persentase sebesar $40 \%$. Responden dengan usia $\leq 15$ tahun sebesar $25 \%$ sedangkan responden usia 26 - 35 tahun $23 \%$. Responden dengan usia 36 - 45 tahun sebesar $10 \%$ dan sisanya $2 \%$ adalah responden yang berusia $\geq 46$ tahun. Ini menunjukkan bahwa pengunjung destinasi wisata Pinus Pengger masih berusia remaja.

\section{Karakteristik Responden Berdasarkan Jenis Kelamin}

Tabel 2. Karakteristik Responden Berdasarkan Jenis Kelamin

\begin{tabular}{ccc}
\hline Jenis Kelamin & Frekuensi & $\begin{array}{c}\text { Prosentase } \\
\%\end{array}$ \\
\hline Laki - laki & 44 & 44 \\
Perempuan & 56 & 56 \\
Total & 100 & 100 \\
\hline
\end{tabular}

Sumber: Data Primer

Berdasarkan Tabel 4 dapat dilihat bahwa responden penelitian ini lebih banyak perempuan yaitu sebanyak $56 \%$ sedangkan reponden laki-laki sebanyak 44\%. Hal tersebut menunjukkan bahwa pengunjung destinasi wisata Pinus Pengger mayoritas adalah Perempuan. 
Karakteristik Responden Berdasarkan Tempat Tinggal

Tabel 3. Karakteristik Responden Berdasarkan Tempat Tinggal

\begin{tabular}{lcc}
\hline \multicolumn{1}{c}{ Tempat Tinggal } & Frekuensi & Prosentase \% \\
\hline $\begin{array}{l}\text { Wilayah Kabupaten } \\
\text { Bantul }\end{array}$ & 14 & 14 \\
$\begin{array}{l}\text { Luar Wilayah } \\
\text { Kabuapaten Bantul }\end{array}$ & 65 & 65 \\
$\begin{array}{l}\text { Luar Yogyakarta } \\
\quad \text { Total }\end{array}$ & 21 & 21 \\
\hline
\end{tabular}

Sumber: Data Primer

Berdasarkan Tabel 5 dapat dilihat bahwa jumlah responden yang bertempat tinggal di Kabupaten Bantul sebanyak 14\%. Responden Luar Kabupaten Bantul Provinsi DIY yaitu $65 \%$ dan responden luar DIY sebanyak $21 \%$. Hal tersebut menunjukkan bahwa pengunjung dari luar wilayah kabupaten Bantul merasa tertarik untuk mengunjungi destinasi wisata Pinus Pengger.

\section{Karakteristik Responden berdasarkan Kepemilikan Akun Instagram}

Tabel 6. Karakteristik Responden Berdasarkan Kepemilikan Akun Instagram

\begin{tabular}{lc} 
& Kepemilikan Akun Instagram \\
\hline & Memiliki Akun Instagram \\
\hline Ya & 83 \\
Tidak & 17 \\
Jumlah & 100
\end{tabular}

Sumber: Data Primer

Tabel 6 menunjukkan bahwa dari 100 responden yang mengunjungi destinasi wisata Pinus Pengger sebanyak 83 memiliki akun instagram, sedangkan sisanya yaitu sebanyak 17 responden tidak memiliki akun instagram. Hal ini mengindikasikan bahwa instagram merupakan salah satu pengaruh bagi pengunjung untuk mengunjungi destinasi wisata Pinus Pengger.

\section{Hasil Pengujian Data}

\section{Hasil Uji Validitas}

Uji validitas digunakan untuk mengukur sah atau tidaknya suatu kuesioner. Kuesioner dikatakan valid jika pertanyaan pada kuesioner mampu mengungkapkan sesuatu yang akan diukur oleh kuesioner tersebut.

Terdapat tiga variabel yang menjadi bahan penelitian yaitu Electronic Word of Mouth,
Daya Tarik dan Keputusan Berkunjung. Dari masing-masing pertanyaan pada variabel baik independ maupun dependen ternyata memiliki nilai $r$ hitung lebih besar dari $r$ tabel sebesar 0.361, sehingga datanya dapat dikatakan valid. Setelah diketahui penyataan dalam setiap variabel adalah valid, maka pengujian akan dilanjutkan untuk mengukur konsistensi pernyataan dalam kuesioner dengan uji reliabilitas.

\section{Uji Realibilitas}

Pengujian reliabilitas bertujuan untuk mengukur tingkat kemampuan suatu instrumen sehingga dapat menghasilkan data yang konsisten dan bebas dari kesalahan. Teknik yang digunakan untuk menentukan reliabilitas penelitian ini alat pengukurnya adalah teknik alpha cronbach, dimana indeks reliabilitas dinyatakan reliabel jika harga $r$ yang diperoleh paling tidak 0,60 .

Nilai-nilai yang ada dimasukkan ke dalam rumus, dan menghasilkan nilai koefisien reliabilitas.

Pada uji reliabel, nilai Alpha Cronbach Electronic Word of Mouth, Daya tarik dan Keputusan berkunjung lebih besar dari 0,6 yang artinya seluruh item dinyatakan reliabel.

\section{Hasil Uji Multikolinearitas}

Pendeteksian problem multikolinearitas dapat dilihat dari nilai Variace Inflation Factor(VIF). Jika nilai VIF kurang dari 10, maka terdapat gejala multikolinearitas. Sebaliknya, jika nilai VIF lebih dari 10 dan nilai tolerance lebih dari 0.10 , maka tidak ada gejala multikolinearitas (Gani, 2015).

\begin{tabular}{|c|c|c|}
\hline \multirow{2}{*}{ Variabel } & \multicolumn{2}{|c|}{ Colinearity Statistics } \\
\hline & Tolerance & VIF \\
\hline Electronic word of Mouth & ,978 & 1,023 \\
\hline Daya Tarik & ,978 & 1,023 \\
\hline
\end{tabular}

Sumber: Data Primer

Dari tabel 9 dapat diketahui: (1) Nilai Tolerance variabel Electronic Word of Mouth (X1) yakni 0,978 lebih besar dari 0,10. Sementara itu, nilai VIF variabel Electronic 
Word of Mouth (X1) yakni 1,023 lebih kecil dari 10,00. Sehingga dapat disimpulkan tidak terjadi multikolinearitas (2) Nilai Tolerance variabel Daya Tarik (X2) yakni 0,978 lebih besar dari 0,10. Sementara itu, nilai VIF variabel Daya Tarik (X2) yakni 1,023 lebih kecil dari 10,00. Sehingga dapat disimpulkan tidak terjadi multikolinearitas.

\section{Hasil Uji Hipotesis}

\section{Hasil Uji T}

Uji ini digunakan untuk mengetahui apakah model regresi pada variabel electronic word of mouth dan daya tarik secara parsial berpengaruh positif dan signifikan terhadap keputusan pengunjung di destinasi wisata Pinus Pengger. Adapaun data yang diperoleh adalah sebagai berikut:

$\mathrm{Y}=15.617+0.632 \mathrm{X}_{1}+0.022 \mathrm{X}_{2}+\mathrm{E}$

Berdasarkan hal tersebut maka : (1) Nilai t hitung variabel electronic word of mouth (X1) yaitu 3,361 lebih lebih kecil daripada t tabel sebesar 1,985, maka Ho ditolak dan $\mathrm{Ha}$ diterima. Sehingga Electronic Word of Mouth berpengaruh terhadap keputusan berkunjung wisatawan. (2) Nilai t hitung variabel Daya Tarik (X2) yaitu 0.089 lebih lebih kecil daripada $\mathrm{t}$ tabel sebesar 1,985, maka Ho diterima dan Ha ditolak. Sehingga Daya Tarik tidak berpengaruh terhadap keputusan berkunjung wisatawan.

\section{Hasil Uji F}

Dari Uji F fapat diketahui bahwa Nilai Fhitung sebesar 5,951 lebih besar dari F tabel 2,70, maka Ho ditolak dan Ha diterima. Sehingga Electronic word of mouth dan Daya Tarik secara bersama - sama berpengaruh terhadap keputusan berkunjung wisatawan.

\section{Koefisien Determinasi}

Koefisien determinasi ini digunakan untuk mengetahui seberapa besar pengaruh variabel-variabel bebas memiliki pengaruh terhadap variabel terikatnya. Nilai koefisien determinasi ditentukan dengan nilai Adjusted $R$ Square.

Hasil perhitungan regresi menunjukkan bahwa koefisien determinasi (Adjusted $R$
Square) yang diperoleh sebesar 0.255. Hal ini berati $25.5 \%$ keputusan berkunjung di Pinus Pengger dipengaruhi oleh variabel electronic word of mouth dan daya tarik, sedangkan sisanya yaitu $74.5 \%$ keputusan berkunjung di Pinus Pengger dipengaruhi oleh variabel lainnya yang tidak diteliti pada penelitian ini.

Berdasarkan hasil analisis karekteristik responden dapat diketahui bahwa sebagian besar responden berusia 16 - 25 tahun dengan presentase $40 \%$. Responden perempuan lebih banyak daripada responden laki-laki meskipun jumlahnya tidak terpaut jauh yaitu perempuan sebanyak 56 dan laki laki sebanyak 44. Dilihat dari tempat tinggal, responden pada penelitian ini mayoritas berasal dari luar wilayah kabupaten bantul dengan presentase $65 \%$. Hasil analisis karakteristik terhadap kepemilikan akun instaram menunjukkan bahwa sebagian besar responden yang memiliki akun instagram sebanyak 83.

Berdasarkan Uji $\mathrm{T}$ dapat dijelaskan dalam pembahasan ini bahwa: (1) hasil penelitian ini menujukkan secara parsial variabel Electronic Word of Mouth berpengaruh terhadap keputusan berkunjung, artinya harus diperhatikan karena Electronic Word of Mouth berpengaruh positif terhadap Keputusan Berkunjung di Destinasi Wisata Pinus Pengger. Hal ini mengindikasikan semakin baik Electronic Word of Mouth maka semakin meningkat keputusan berkunjung wisatawan ke destinasi wisata Pinus Pengger, dengan kata lain adanya komunikasi electronic word of mouth yang terjadi di media sosial, sehingga hal tersebut menjadi dorongan atau rangsangan internal yang kuat yang memotivasi followers akun media sosial untuk melakukan tindakan, dimana dorongan ini dipengaruhi oleh stimulus berupa sharing informasi antar pengguna maupun posting destinasi wisata dari admin akun tersebut. Alasan tersebut sejalan dengan pendapat yang diungkapkan oleh Kotler (2000) yang menyatakan bahwa minat merupakan suatu dorongan, atau rangsangan internal yang kuat yang 
memotivasi tindakan dimana dorongan ini dipengaruhi oleh stimulus.

Hasil penelitian ini konsisten dengan hasil penelitian Aprilia, dkk (2015) meneliti tentang Pengaruh electronic word of mouth terhadap minat berkunjung serta dampaknya pada keputusan berkunjung (survei pada pengunjung tempat wisata "jawa timur park 2" kota batu). Berdasarkan hasil penelitian electronic word of mouth berpengaruh secara parsial terhadap keputusan berkunjung dan minat berkunjung berpengaruh terhadap keputusan berkunjung. (2) Hasil penelitian ini menunjukkan bahwa variabel Daya Tarik secara parsial tidak berpengaruh terhadap keputusan berkunjung. Daya tarik tidak berpengaruh terhadap keputusan berkunjung, artinya semakin menarik suatu daya tarik wisata tidak akan mempengaruhi keputusan berkunjung wisatawan. Hasil penelitian ini konsisten dengan hasil penelitian Irma (2016) meneliti tentang pengaruh electronic word of mouth, Daya Tarik dan Lokasi terhadap keputusan berkunjung wisatawan di Curung Sidoarjo. Dalam penelitian tersebut secara parsial menujukkan bahwa Daya Tarik tidak berpengaruh terhadap keputusan berkunjung wisatawan di Curung Sidoarjo

Hasil Uji F pada penelitian ini menunjukkan bahwa secara bersama - sama Variabel Electronic Word of Mouth dan Daya Tarik secara bersama - sama memiliki pengaruh yang positif terhadap kunjungan wisatawan di destinasi wisata Pinus Pengger. Hal ini menujukkan bahwa perlu adanya perhatian dari pengelola terkait pada variabel Electronic Word of Mouth dan Daya Tarik agar wisatawan yang berkunjung ke Pinus Pengger lebih meningkat. Besarnya pengaruh Electronic Word of Mouth dan Daya Tarik secara bersama - sama berpengaruh terhadap keputusan berkunjung wisatawan di Pinus Pengger adalah sebesar $25.5 \%$, sedangkan sisanya yaitu $74.5 \%$ keputusan berkunjung di Pinus Pengger dipengaruhi oleh variabel lainnya yang tidak diteliti pada penelitian ini.

Hasil penelitian ini juga sejalan dengan hasil penelitian Susanto (2020) yang meneliti tentang Pengaruh Pomosi Media Sosial dan
Daya Tarik Wisata terhadap minat berkunjung kembali di objek Wisata Edukasi Manyung. Hasil penelitian tersebut menujukkan bahwa secara bersama promosi media sosial berpengaruh positif dan signifikan dan daya tarik wisata juga berpengaruh secara signifikan terhadap minat berkunjung kembali di obyek wisata edukasi Manyung.

Sejalan dengan hasil penelitian Riantika (2016) yang meneliti tentang Pengaruh electronic word of mouth, daya tarik, dan lokasi terhadap keputusan berkunjung wisatawan di Curug Sidoharjo. Berdasarkan hasil penelitian secara bersama-sama electronic word of mouth, daya tarik, dan lokasi berpengaruh terhadap keputusan berkunjung wisatawan di Curug Sidoharjo dan secara parsial electronic word of mouth dan lokasi berpengaruh terhadap keputusan berkunjung wisatawan, sedangkan daya tarik tidak berpengaruh keputusan berkunjung wisatawan.

\section{SIMPULAN}

Pengaruh parsial pada setiap variabel menunjukkan bahwa Variabel Electronic Word of Mouth berpengaruh secara signifikan terhadap keputusan berkunjung wisatawan di Pinus Pengger. Keputusan berkunjung para responden dalam penelitian ini dimungkinkan dipengaruhi oleh variabel lain yang tidak diteliti pada penelitian ini. Variabel Daya Tarik tidak berpengaruh terhadap keputusan berkunjung. Semakin menarik obyek wisata ataupun sebaliknya tidak akan mempengaruhi keputusan berkunjung wisatawan. Keputusan berkunjung wisatawan dapat terjadi karena variabel lain.

Sedangkan hasil penelitian menunjukkan bahwa secara bersama - sama variabel electronic word of mouth dan daya tarik berpengaruh terhadap Keputusan Berkunjung di Pinus Pengger, sehingga apabila kedua variabel ini diperhatikan secara bersamasama maka akan menarik keputusan berkunjung. Dari nilai koefisien determinasi 
menujukkan bahwa $25.5 \%$ keputusan berkunjung di Pinus Pengger dipengaruhi oleh variabel electronic word of mouth dan daya tarik, sedangkan sisanya yaitu $74.5 \%$ keputusan berkunjung di Pinus Pengger dipengaruhi oleh variabel lainnya yang tidak diteliti pada penelitian ini.

\section{REFERENSI}

Aprilia, F. (2015). Pengaruh Word Of Mouth Terhadap Minat Berkunjung Serta Dampaknya Pada Keputusan Berkunjung (Survei pada Pengunjung Tempat Wisata "Jawa Timur Park 2" Kota Batu). Jurnal Administrasi Bisnis, 24(1).

Austriana, I. (2005). Analisis Faktor yang Mempengaruhi Penerimaan Daerah dari Sektor Pariwisata. Universitas Diponegoro.

Boyd, D. M., \& Ellison, N. B. (2007). Social network sites: Definition, history, and scholarship. Journal of computermediated communication, 13(1), 210230.

Charo, N., Sharma, P., Shaikh, S., Haseeb, A., \& Sufya, M. Z. (2015). Determining the impact of ewom on brand image and purchase intention through adoption of online opinions. International Journal of Humanities and Management Sciences, 3(1), 41-46.

Cheung, C. M., \& Thadani, D. R. (2010). The Effectiveness of Electronic Wordof-Mouth Communication: A Literature Analysis. Bled eConference, 23, 329-345.

Gani, I., \& Amalia, S. (2015). Alat Analisis Data: Aplikasi Statistik untuk Penelituan Bidang Ekonomi dan Sosial. Penerbit Andi.

Hasan, A., \& Setiyaningtiyas, N. W. (2015). Pengaruh Electronic Word of Mouth pada Media Sosial Facebook terhadap Keputusan Berkunjung ke Desa Wisata Nglanggeran Gunungkidul. Media Wisata, 13(1).

Herdiana, Lisa. 2012 "Daya Tarik dan Kawasan Wisata". http://lisaherdiana.blogspot.co.id/2012/ 04/daya-tarik-dan-kawasan- .html. Diakses pada tanggal 26 Juli 2020

Hennig-Thurau, T., Walsh, G., \& Walsh, G. (2003). Electronic word-of-mouth: Motives for and consequences of reading customer articulations on the Internet. International journal of electronic commerce, 8(2), 51-74.

Illah, A. N., Sularso, R. A., \& Irawan, B. (2019). Pengaruh Citra Destinasi dan E-WOM di Media Sosial Instagram serta Persepsi Konsumen Terhadap Keputusan Berkunjung ke Objek Wisata B29 di Kabupaten Lumajang. $e$ Journal Ekonomi Bisnis dan Akuntansi, 6(2), 164-170.

Jalilvand, M. R., \& Samiei, N. (2012). The effect of electronic word of mouth on brand image and purchase intention. Marketing Intelligence \& Planning.

Junaida, E. (2019). Pengaruh Daya Tarik Wisata dan Word Of Mouth terhadap Keputusan Wisata Berkunjung ke Taman Hutan Kota di Kota Langsa. Jurnal Samudra Ekonomi dan Bisnis, 10(2), 146-155.

Kertamukti, R. (2015). Instagram Dan Pembentukan Citra (Studi Kualitatif Komunikasi Visual dalam Pembentukan Personal Karakter Account Instagram@ basukibtp). Profetik: Jurnal Komunikasi, 8(1).

Kiralova, A., \& Pavliceka, A. 2015. Development of Social Media Strategies in Tourism Destination. Procedia - Social and Behavioral 
Sciences, 175, 358-366.

Martono, Nanang. 2014. Metode Penelitian Kuantitatif Analisis Isi dan Analisis Data Sekunder. Jakarta: PT Raja Grafindo Persada.

Mitchell, J. (2017). Instagram Marketing for Beginners: How to make 10,000\$ per month. Lizard Publishing via PublishDrive.

Riantika, I. (2016). Pengaruh Electronic Word Of Mouth, Daya Tarik, Lokasi Terhadap Keputan Berkunjung Wisatawan di Curug Sidoharjo. Skripsi. Fakultas Ekonomi: USD Yogyakarta.

Sari, F., \& Pangestuti, E. (2018). Pengaruh Electronic Word Of Mouth (E-wom) Terhadap Minat Berkunjung Dan Keputusan Berkunjung (Studi Pada Wisata Coban Rais BKPH Pujon). Jurnal Administrasi Bisnis, 54(1), 189-196.

Schiffman dan Kanuk. 2008. Perilaku Konsumen. Edisi 7. Jakarta : Prentice Hall.

Sumarwan, U. (2011). Perilaku konsumen: Teori dan penerapannya dalam pemasaran. Bogor: Ghalia Indonesia.

Susanto, B., \& Astutik, P. (2020). Pengaruh Promosi Media Sosial Dan Daya Tarik Wisata Terhadap Minat Berkunjung Kembali Di Obyek Wisata Edukasi Manyung. RISK: Jurnal Riset Bisnis dan Ekonomi, 1(1), 36-46.

Suwarduki, P. R., Yulianto, E., \& Mawardi, M. K. (2016). Pengaruh electronic word of mouth terhadap citra destinasi serta dampaknya pada minat dan keputusan berkunjung (survei pada followers aktif akun instagram indtravel yang telah mengunjungi destinasi wisata di Indonesia). Jurnal Administrasi Bisnis, 37(2), 1-10.
Putri EA. 2013. Aplikasi Instagram sebagai Media Komunikasi Pemasaran Online Shop. [skripsi]. [Internet]. [Diunduh pada tanggal 28 Juli 2020]. diunduh pada:

http://eprints.upnjatim.ac.id/5020/1/file $\underline{1 . p d f}$

Sunyoto, D. (2014). Dasar-Dasar Manajemen Pemasaran (Konsep, Strategi, dan Kasus) Yogyakarta. CAPS (Centre of Academic Publising Service).

Undang-Undang Republik Indonesia No. 10 tahun 2009 tentang Kepariwisataan

Zaenuri, M. (2012). Perencanaan strategis kepariwisataan daerah konsep dan aplikasi. Jogjakarta: e-Gov Publishing.

Website Pendidikan Ekonomi. 2012 "Pengertian Komunikasi Word of Mouth (WOM)”.

http://www.pendidikanekonomi.com/2012/07 /pengertian-komunikasi-word-ofmouth-wom.html. Diakses pada tanggal 26 Juli 2020

Weiss, M., Loock, C. M., Staake, T., Mattern, F., \& Fleisch, E. (2010, December). Evaluating mobile phones as energy consumption feedback devices. In International Conference on Mobile and Ubiquitous Systems: Computing, Networking, and Services (pp. 63-77). Springer, Berlin, Heidelberg.

Wibisono, A. D. (2020). Pengaruh Advertising, Knowledge, dan Word of Mouth Terhadap Keputusan Menjadi Nasabah Bank Syariah Dengan Minat Sebagai Variabel Intervening (Studi Pada Masyarakat Kota Salatiga.

Yogyakarta, D. P. D. I. (2016). Statistik kepariwisataan 2016. Yogyakarta: Dinas Pariwisata DIY. 
Yogyakarta, D. P. D. I. (2017). Statistik kepariwisataan 2017. Yogyakarta: Dinas Pariwisata DIY.

Yogyakarta, D. P. D. I. (2018). Statistik kepariwisataan 2018. Yogyakarta: Dinas Pariwisata DIY.

Yogyakarta, D. P. D. I. (2019). Statistik kepariwisataan 2019. Yogyakarta: Dinas Pariwisata DIY.

Zarrella, D. (2009). The social media marketing book. " O'Reilly Media, Inc.".

\section{PROFIL PENULIS}

Yuliyani, merupakan dosen pariwisata di Akademi Pariwisata STIPARY, Yogyakarta, email: yulia.stipary@gmail.com

Id Scholar:

https://scholar.google.com/citations?hl=id\&a uthuser $=1 \&$ user $=8 \mathrm{jky} 1 \mathrm{FYAAAAJb}$

Suharto, merupakan dosen pariwisata di Akademi Pariwisata STIPARY, Yogyakarta, Indonesia, email: hartamas1970@gmail.com

Id Scholar:

https://scholar.google.com/citations?hl=id\&a uthuser $=1 \&$ user $=$ OjaIsx0AAAAJ 